de soro sangüíneo de exemplares de Trachemis scrypta de ambos os sexos. As amostras foram obtidas através de punção do seio venoso occiptal, acondicionadas em frascos com vácuo $\mathrm{e}$ ativador de coágulo e encaminhadas ao Laboratório de Análises Clínicas da Unidade Hospitalar para Animais de Companhia da PUC-PR, onde foram imediatamente processadas através de método de análise de íons seletivos utilizando-se o aparelho modelo ISELAB ${ }^{\mathfrak{a}}$ da marca DRAKE ${ }^{a}$. A média e desvio-padrão obtidos para sódio foram 124,89 e $3,58(\mathrm{mmol} / \mathrm{L})$ e para o potássio 3,26 e $0,49(\mathrm{mmol} / \mathrm{L})$. As dosagens de eletrólitos em répteis possuem grande importância clínica em casos de diarréia, pois diferente dos mamíferos, os répteis sofrem uma perda importante dos íons sódio e potássio pelo trato gastrointestinal (MADER, 1996). Em casos de acompanhamento de terapêutica prescrita, adequação de dietas nutricionais, variações térmicas e doenças do trato urinário as dosagens de sódio e potássio são de grande auxilio (MADER, 1996). Os métodos mais comuns para realização de dosagem de eletrólitos limitam por sua dificuldade e alto custo sua utilização em auxílio diagnóstico, o método de dosagem de íons seletivos ameniza muito estas dificuldades.

Sá, L.R.M'; Mirandola, R.M.S. ${ }^{2}$; Duarte, M.I.S. ${ }^{3}$

\section{9 - Caracterização laboratorial da enteropatia observada na Síndrome de Emagrecimento Progressivo de Sagüis mantidos em cativeiro}

1- Departamento de Patologia da Faculdade de Medicina Veterinária e Zootecnia da Universidade de São Paulo-SP, São Paulo-SP

2- Departamento de Clínica Médica da Faculdade de Medicina Veterinária e Zootecnia da Universidade de São Paulo-SP, São Paulo-SP

3- Departamento de Patologia da Faculdade de Medicina da Universidade de São Paulo, São Paulo-SP

A Síndrome de Emagrecimento Progressivo (SEP) é uma das principais causas de morbidade e mortalidade de sagüis mantidos em cativeiro de diversas coleções no mundo, incluindo no Brasil. É caracterizada, de forma geral, por perda de peso progressiva, diarréia intermitente, anemia, atrofia muscular, paralisia dos membros posteriores, alopecia da cauda, infecção bacteriana ou fúngica secundária e óbito. Diarréia, emagrecimento e anemia são alteraçōes clínicas não específicas de distúrbios entéricos, incluindo síndrome de má absorção. As síndromes de má-absorçào podem apresentar origem pré-entérica, entérica ou pós-entérica, e para diferenciação são necessários exames laboratoriais, tais como: função pancreática exócrina e teste de absorção de D-xilose. Este trabalho tem por objetivo avaliar a função intestinal de sagüis com sintomatologia clínica da SEP de forma a caracterizar laboratorialmente o processo envolvido. Os sagüis doentes foram selecionados baseados nos sintomas gerais da doença, como perda de peso, diarréia, anemia ou com histórico de uma destas alterações. O grupo controle foi formado por saguiis sadios. Todos os animais eram mantidos em cativeiro no Criadouro Mucky, Jundiai - SP, no período de janeiro de 2000 a outubro de 2001. O grupo de doentes constituiu-se de 22 saguiis, enquanto o grupo controle por 21 . Amostras de fezes e urina foram colhidas e processadas de forma semelhantes de todos os 43 animais. A função pancreática exócrina foi avaliada segundo método de rotina para exame coprológico funcional, utilizando Teste de digestão em tubo de gelatina para pesquisa de tripsina fecal, e o teste de absorção de D-xilose foi utilizado para avaliar a função absortiva do jejuno. Os resultados laboratoriais demonstraram fezes normais a intermitentes fezes volumosas, acizentadas ou amareladas, pastosas com presença de fibras musculares, gotículas de gorduras (esteatorréia), amido e atividade proteolítica normal a intermitente, no início dos sintomas, e progressivamente se torna ausente, conforme a evolução da doença. A avaliação da eliminaçào de $\mathrm{D}$-xilose na urina demonstrou diferença entre os dois grupos analisados $(\mathrm{p}=0,0023)$, com menores valores no grupo índice. Com os resultados alcançados pode-se caracterizar a enteropatia observada no sagüis doentes como uma má-absorção devido a redução da capacidade absortiva do jejuno, traduzida clinicamente por esteatorréia, diarréia, emagrecimento, anemia e menor D-xilosúria. 